\title{
KAN CALVINISTIESE BEGINSELS TOT ALGEMEEN GELDIGE KENNIS LEI?
}

Vollenhoven maak in sy werk Geschiedenis der Wijsbegeerte (1950, p. 40) die belangrike stelling dat alle skepsele sowel 'n universele (of algemeengeldige) as 'n individuele sy vertoon, en dat dié twee sye altyd en oral tegelyk voorkom as twee gelykwaardige kante. Elke skepsel vertoon dus die ontiese grondtrek van universaliteit en individualiteit. Dit is een grondtrek met twee gelyktydige en gely kwaardige sye.

Die universele of algemeen-geldige sy van 'n struktuur soos die staat dui op die onveranderbaarheid en konstantheid daarvan. Die staat bly altyd staat, die mens mens, die hond hond en die skool skool. Vir elke soort en tipe is daar universele en onveranderbare hoedanighede en beginsels gegee wat die eie-geaardheid en eie-soortigheid daarvan handhaaf. 'n Hond sal nooit 'n boom kan word nie, en 'n onderwysstelsel nooit 'n kerk nie. Die hoedanighede wat die identiteit daarvan bepaal, is universeel en algemeen geldig: dit geld altyd en oral vir daardie skepsel. 'n Skool sal altyd en oral 'n skool bly ongeag of dit nou in die Middeleeue of twintigste eeu bestaan en of dit in Japan, Amerika of in Suid-Afrika voorkom.

Die individuele of besondere sy van 'n skepsel dui op die veranderlike en aanpasbare kant daarvan. As gevolg van die wisselende omstandighede van plek en tyd word dieselfde soort op verskillende wyses geindividualiseer. Die universele hoedanighede van byvoorbeeld die mens is in elke mens anders vergestalt as gevolg van die verskil in oorerwing en omgewing. $\mathrm{Ek}$ is dus universeel én individueel: ek is 'n mens (my universeel-menslike hoedanighede) maar ek is ook ek (my besondere hoedanighede). Die Suid-Afrikaanse onder onderwysstelsel is tegelyk en gelykwaardig universeel én individueel omdat dit eerstens 'n onderwysstelsel is en tegelyk daarmee ook die Suid-Afrikaanse onderwysstelsel is.

Die wetenskaplike soek onder andere altyd na die universele of algemeengeldige (die wette, norme, eienskappe) van die strukture binne sy studieveld in hulle verskillende openbaringe en vergestaltinge oor die wêreld heen, dit wil sê na die universele én individuele sye as twee gelyktydige en gelykwaardige kante daarvan. Die pedagoog vra na byvoorbeeld die universaliteit én individualiteit van die les, die opvoedeling, die kurrikulum, die werklikheid, die skool, die onderwysstelsel, ensovoorts; die fisikus na die universaliteit én individualiteit van onder andere elke tipe materie, die bioloog na die univer- 
saliteit én individualiteit van onder andere elke plant-en diersoort, ensovoorts. As die natuurwetenskaplike vasstel dat materie by verhitting uitsit of dat 'n verbinding van twee waterstofmolekules met een suurstofmolekuul altyd water vorm, dan ontdek hy daarmee 'n algemeen-geldige natuurwet. Uitsetting by verhitting is wetmatige gedrag, wat konstant en onveranderbaar onder dieselfde voorwaardes bly. Wanneer die pedagoog opmerk dat die onderwysstelsel 'n vervlegtingstruktuur is, dan identifiseer hy 'n universele óf algemeen-geldige struktuurkenmerk daarvan. Daardeur sê hy dat die onderwysstelsel na sy aard 'n samestelling van verskeie soorte samelewingsverbande is. Dit geld altyd en oral vir alle onderwysstelsels oor die wêreld heen: almal is vervlegtingstrukture. Merk hy voorts op dat die samehang van die verskeidenheid strukture die algemeen-geldige beginsel van die behoud van elkeen se soewereiniteit wat dit in eie kring besit geld, dan dui hy daarmee aan dat elke samelewingsverband binne die onderwysstelsel bepaalde grense ontvang het waarbinne dit sy moontlikhede met verantwoordelikheid moet vervul. Met ander woorde vir die staat, kerk, gesin, bedryf, skool, ensovoorts, geld bepaalde verantwoordelikhede wat dit ooreenkomstig die gestruktureerdheid daarvan besit en wat dit nie mag oorskry nie. Doen die staat meer as waarvoor dit die nodige norme ontvang het deur byvoorbeeld aan die skool voor te skryf wat en hoe om te onderrig, dan oorskry dit sy grense en word daar dusdoende teen die skool se vryheid om in eie bevoegdheid sy taak te verrig oortree. Of, word die ouers nie toegelaat om hulle reg tot medeseggenskap in die onderwys na te kom nie, dan word daar teen die soewereiniteit in eie kring van die gesin gesondig en word dit ten opsigte van die onderwys onvry.

Maar waar en hoe vind die wetenskaplike die algemeen-geldige hoedanighede van die strukture? Hoe weet hy dat dit algemeen-geldig is? In sekere gevalle is dit maklik vasstelbaar terwyl dit veral in die geesteswetenskaplike studies gewoonlik baie moeilik is. Selfs in natuurwetenskaplike ondersoeke stuit die mens dikwels op onbewysbare sake soos wanneer die lewe in die sel begin. Is dit iets wat byvoorbeeld spontaan begin wanneer die regte stowwe in die regte hoeveelhede onder optimaal gunstige omstandighede in aanraking met mekaar gebring word (lewe uit dood), is dit so dat slegs lewe lewe kan wek, dit wil sê, lewe word van een lewende skepsel in 'n ander voortgeplant (lewe uit lewe)? Hier is dus sprake van verskillende sieninge en teorieë oor waarhede wat nie eksperimenteel bewysbaar is nie. Elkeen meen dat hy deur sy teorie die waarheid weergee, dit wil sế egte, outentieke, algemeengeldige en universele kennis daarmee stel.

Die kruks van die saak is dat wetenskap deur die mens bedryf word, en die mens is altyd subjektief in sy beskouinge en aannames. Die spreekwoord 
lui tereg ook: soveel hoofde soveel sinne. As gevolg van sy hartsgerigtheid (die religieuse ingesteldheid van die selfheid) beskik elke wetenskaplike oor sekere aannames, insigte en "vanselfsprekendhede" wat gesamentlik bekend staan as sy voorveronderstellinge (in onderskeiding van sy vooroordele soos emosies, voor- en afkeure, verwagtinge, ensovoorts, wat wetenskap vervais). Dit hou verband met beginsels. Bewus of onbewus opereer die wetenskap aan die hand daarvan. Vir die wetenskaplike is dit fundamenteel en leidend (Stoker, 1969, p. 31). Dit is regulatiewe ideè (Hommes, 1972, p. 98) wat die wetenskaplike navorsing langs bepaalde weé lei en dit op daardie wyse be vrug. Die navorsingsresultate (formuleringe, teorieè, skemas, modelle, uitsprake, ensovoorts) word dus wesentlik bepaal deur die voorveronderstellinge of beginsels wat die wetenskaplike huldig. Begrip van 'n wetenskaplike se bevinding vereis dus 'n begrip van sy voorveronderstellinge. Dit maak al die verskil. Die uniekheid en feitlik onbeperkte kwaliteite en moontlikhede van die mens en sy altyd anderse interpretasie van sake het tot gevolg die voortdurende veranderinge in insigte en teorieè. Ofskoon elke teorie of beskouing 'n poging is om die waarheid (die algemeen-geldige) weer te gee, is dit altyd partikulier, subjektief gekleurd, hipoteties, relatief.

Deur die eeue van wetenskapsbeoefening het daar groot denkskole, strorninge, verwysingsraamwerke en dwaalleringe, ensovoorts, na vore gekom. Baie van hulle besit in ' $n$ mindere of meerdere mate dele van die waarheid. Enkele daarvan is byvoorbeeld die Liberalisme, Eksistensialisme, Progmatisme, Rasionalisme, Realisme, Marxisme, Positivisme, Calvinisme, ensovoorts. Geeneen van die denkskole en hulle teorieé alleen het ' $n$ absolute suiwer en volkome korrekte siening van sake nie. Dit is trouens dan ook nie vir die mens moontlik om so 'n ware kennis van sake te bekom nie - eenvoudig omdat dit die mens is wat wetenskap beoefen: afvallig, gebroke, in sonde ontvang en gebore, aards, vleeslik, sterflik, feilbaar en wat slegs ten dele ken.

Daarmee kom ek by die wese van die vraag waarom dit hier gaan, naamlik of die Calvinistiese beskouing van sake op algemeen-geldigheid aanspraak kan maak. Soos alle denkskole op bepaalde beginsels gebaseer is, so is die Calvinistiese skool op Skriftuurlike en dus Christelike beginsels gevestig. Op dié vraag kan ja en nee geantwoord word. Antwoord ons nee, dan is dit eenvoudig omdat ook die Calvinisme steeds 'n menslike interpretasie van die Bybel-beginsels bly, want dit word vandag op talle wyses geinterpreteer en ingesien. Daar bestaan talle variasies van Christelike denkskole en ook hier geld die vraag: Watter Christelike denkskool sien die waarheid die suiwerste? 'n Ja-antwoord moet egter gekwalifiseer word. Dit hang daarvan af of die Calvinisme 'n suiwer en korrekte menslike interpretasie van die Goddelike beginsels is. En nou is die vraag: Is die Christelike beginsels en norme die 
waarheid? - ongeag of dit 'n Christen of nie-Christen is wat daarmee werk? Is dit moontlik om aan die hand daarvan wel tot die waarheid te kom? Myns insiens is dit nie 'n saak van geloof alleen nie. Dit hoef nie alleen geglo te word nie; dit is ook bewysbaar; dit is sigbaar; dit is daar vir elke mens om self te toets en te beproef. En die een wat dit eenmaal raakgesien het, sal nooit weer oor die egtheid daarvan twyfel nie, want dit is al wat letterlik werk omdat dit so eg en natuurlik is en omdat dit in ooreenstemming is met die ware aard van die skepsele. Enkele voorbeelde behoort die saak genoegsaam te verduidelik.

Eerstens: Teorieë oor die vryheid van die mens kan hoofsaaklik in drie groepe verdeel word, naamlik dié wat menslike vryheid hoegenaamd ontken (die universalisme), dié wat sy vryheid as onbeperk beskou (die individualisme) en dié wat beide sy vryheid maar ook sy gebondenheid erken (Calvinisme). In eersgenoemde geval word die mens se vryheid ontken; is hy slegs deel van die groter geheel (die gemeenskap), 'n massamens met geen seggenskap oor sy eie lewe en sake nie, ondergeskik aan mense, magte en strukture wat oor hom gestel is en wat hy ongevraagd moet gehoorsaam. In die tweede geval word hy as onbeperk vry beskou. Hy kan doen, sê en dink wat hy wil, is aan niks of niemand verantwoordelikheid verskuldig nie, besluit mateloos self oor sake, is in volle beheer oor alles en bly heer en meester van sy eie lewe. Die vraag is of enige van die twee groepe teoriec oor die mens se vryheid algemeen-geldig kan wees. Die antwoord is voor-die-hand-liggend. Die mens wat van sy kosbaarste besitting, sy vryheid, beroof is, is diep ongelukkig, kan nooit in sy ware element wees nie, kom nooit tot ware lewensvervulling nie. Die mens wat weer mateloos vry is, kan ook nie ware mens wees nie - eintlik is hy onmens, 'n ,dier". Geeneen van die teorieë strook met die ware en natuurlike aard van die mens nie. Eers wanneer die mens sy vryheid ontvang maar gelyktydig en gelykwaardig daarmee ook aan bepaalde norme gebind word deur in alles dit altyd te gehoorsaam, hom daaromtrent te verantwoord, dan word hy waarlik mens, dan begin hy lewe, kom hy in sy element. Beantwoord hy aan sy ware aard en wese, bereik hy sy ware doel, kan hy sy lewe begin vervul. In die lig van die Calvinisme sal die wetenskapsteorie oor die mens se vryheid eenvoudig moet lui: vryheid-tot-verantwoordelikheid.

'n Tweede voorbeeld handel oor medemenslike liefde. Hoe moet die mens sy medemens liefhê? Wat is die bedoelde aard daarvan? Moet ek myself as ' $t$ ware haat en al my liefde op die ander uitstort (altruisme) of moet ek net myself liefhê (egoïme) of moet ek myself net so liefhê soos my naaste (Christelike norm)? Die antwoord is vanselfsprekend: Hy wat net vir die ander leef, word hulle slaaf, en hy wat net vir homself leef, word 'n diep on- 
gelukkige mens wat homself in al sy verhoudinge vasloop. Wanneer die ewewig egter gehandhaaf word, dan kom ek én my naaste in lyn met God se bedoeling vir ons lewens. Só alleen leef ons in ooreenstemming met ons ware geaardheid. Dit werk, want dit is die waarheid. Dit hoef nie geglo te word nie. Almal kan dit sien.

'n Laaste voorbeeld: Watter staatsvorm is die geskikste vir die mens? 'n Demorkasie of 'n outokrasie? Die Bybel gee nie hierop 'n antwoord nie maar dit stel beginsels vir die mens se lewe, sy roeping en sy vryheid. Die vraag wat in die lig daarvan beantwoord moet word, is binne watter staatsvorm hy die ruimte gaan ontvang om God se doel met sy lewe die beste te vervul. Albei kan misluk. Binne die outokrasie is daar weinig ruimte vir vry heid en lewensvervulling. Wanneer die mens se vryheid nie aan behoorlik heidseise binne die demokrasie gebind word nie, is ook dit 'n mislukking. Laasgenoemde bied die grootste ruimte, maar slegs wanneer hy sy verant woordelikheid ten volle aanvaar.

In alle wetenskap gaan dit per slot van sake om die mens in sy roeping. Die mens mag nie verslaaf of onbeperk vrygemaak word sodat hy God nie met volkomenheid kan dien nie. Word hy byvoorbeeld slaaf van die Sabbat (Sondagsverafgoding), dan kan hy God nie meer met 'n volkome liefde dien en Hom alleen bo alle dinge liefhê nie, terwyl hy hom ook nie van die Sabbat mag losmaak nie, omdat hy dan weer die wêreld dien. Die Sabbat is vir die mens gemaak en nie die mens vir die Sabbat nie (Markus 2:27).

Die Calvinis gebruik die Bybel op 'n bepaalde wyse. Dit is nie 'n resepteboek nie, is nie voorskriftelik vir elke saak nie. Dit gee slegs perspektief op die werklikheid, lê grondslae neer, stel beginsels, gee riglyne en daaruit maak hy gevolgtrekkinge wat hom in sy soeke na ware kennis moet lei. „The study of the Scriptures provides an understanding of the theme of the Creation, Fall, Redemption, and the Kingdom of Christ, and of Man's place and task in the world" (Steensma en Van Brummelen, 1977, p. 17). Die gebruik van die Bybel om daanuit die Christelike beginsels wat vir alle skepsele geld en as voorveronderstellinge in die wetenskap gebruik word af te lei, beteken nie dat die wetenskaplike nou alle ander boeke opsy gaan skuif nie. Inteendeel, dit is ,a spiritual eye-opening experience for returning to readin', writin', 'rithmetic with renewed vision" (Spykman, 1977, p. 1). Slegs in die lig van Skrifbeginsels sien die mens die lig, die waarheid, die algemeen-geldige en Godbedoelde wese van die sake raak.

Al is die Calvinisme dan ook slegs een van die menslike interpretasies van algemeen-geldige hoedanighede, dan glo, sien en weet ek dat die wetenskap aan die hand daarvan die getrouste weergawe van die ware, universele en algemeen-geldige kennis van die stand van sake weergee. 


\section{BRONNE}

HOMMES, HJ. VAN EIKEMA, 1972. De Elementaire Grondbegrippe der Rechtswetenschap. Deventer: Kluwer.

SPYKMAN, GJ., 1977. "The place and role of the Bible in the School", in Shaping School Curriculum: a Biblical view, onder redaksie van GJ. Steensma en H.W. van Brummelen.

STEENSMA, GJ. \& VAN BRUMMELEN, H.W., 1977. „Directives for a Biblically grounded curriculum" in Shaping School Curriculum: a Biblical view onder redaksie van GJ. Steensma en H.W. van Brummelen.

STOKER, H.G. 1969. Beginsels en Metodes in die Wetenskap. Johannesburg: Boekhandel De Jong (Edms) Bpk., Tweede onveranderde druk.

VOLLENHOVEN, D.H. Th. 1950. Geschiedenis der Wijsbegeerte 1, Franeker, Wever. 